- Short Communication

\title{
STUDY ON THE INSECT INFESTATION OF DRY FISHES AT SINGRA
}

\author{
FAWZIA ADIB FLOWRA ${ }^{1}$, ANANNYA SEN TUMPA AND MD. TARIQUL ISLAM \\ Department of Fisheries, University of Rajshahi, Rajshahi-6205, Bangladesh
}

Drying is regarded as a traditional, cheapest and simplest method of preservation of fishes. It plays a vital part in the developing countries of the world like Bangladesh. Bala (2000) reported that about $30 \%$ of the freshly harvested fish is spoiled every year due to lack of proper preservation facility in the country and this amount is 0.308 million metric ton and about $40 \%$ of the remaining harvested fish was sun dried and this amount was 0.072 million metric ton. Significant portion of dried fish approximately 622 tons were exported that earns a good amount which is 25.06 crore taka of foreign currency (DoF 2011). Dried fishes are not only economically important but also an important source of animal protein in Bangladesh which supplements $60 \%$ of animal protein (DoF 2012). Graikoski (1998) also reported that, dried fish products are the pre-dominant food bringing vital protein to people in rural areas. Besides protein source dried fishes are also rich in vitamins and minerals, which are often overlooked in developing countries (Hossain and Afroze 1991, Nettleton 1992, Basu and Gupta 2004 and Ross et al. 2007). Dried and drying fishes are susceptible to many types of spoilage which can affect the quality and shelf life. Physical and organoleptic qualities of many traditional sun-dried products are un-satisfactory for human consumption (Nowsad 2005). Damages occurring due to flies and insects are of great significance in open drying under the sun and this is a serious problem in traditional drying. A good number of researchers worked scattered on insect infestation and protection policy (Azam 2002 and Samad et al. 2009) but there is little work particularly in Chalan beel area. Chalan beel is an extensive low land area at the lower Atrai basin in the northeastern region of Bangladesh and spread across the districts of Natore, Naogaon, Pabna and Sirajgang (Samad et al. 2009). It consists of a series of beels connected to one another by various channels during the rainy season. A very dense water network over the entire Chalan beel is formed by rivers and their tributaries. The total area covered being slightly above 150 square miles ( $375 \mathrm{sq}$. $\mathrm{km}$.). Since this area is a great source of fresh water fishes of north-western region of Bangladesh and many people engage with drying activities the present investigation was conducted in different dry fish yards at Singra in Chalan beel area of Natore district to study the conditions of dry fish infestation and the protection policy which are normally used. The studied fish drying yards and their detail information are shown in Table 1. A questionnaire was developed in logical sequence of information include both qualitative and quantitative values of findings, so that the respondents could answer easily and chronologically. A total of 25 dry fish professionals in different drying points was interviewed.

\footnotetext{
${ }^{1}$ Corresponding author: Email: flowrabd@yahoo.com
} 
Table 1. Detail description of the study area.

\begin{tabular}{l|c|c|c|c}
\hline $\begin{array}{l}\text { Location of the } \\
\text { Yards }\end{array}$ & $\begin{array}{c}\text { Area } \\
\text { (Decimal) }\end{array}$ & $\begin{array}{c}\text { Number of fish } \\
\text { drying points }\end{array}$ & $\begin{array}{c}\text { Number of man } \\
\text { power engaged }\end{array}$ & $\begin{array}{c}\text { No. of interviewed } \\
\text { professionals }\end{array}$ \\
\hline $\begin{array}{l}\text { Dakin } \\
\text { Domdoma }\end{array}$ & 33 & 3 & $7-8$ & 4 \\
Zolar Bata & 38 & 3 & $8-9$ & 5 \\
Ningoil & 69 & 4 & $12-15$ & 6 \\
Baria & 18 & 1 & $5-6$ & 2 \\
Chaugram & 15 & 1 & $4-5$ & 3 \\
Kalam & 16 & 1 & $3-4$ & 2 \\
Nazarpur & 19 & 2 & $4-5$ & 3 \\
Dahia & 208 & 15 & $43-52$ & 25 \\
Total & & & & 45 \\
\hline
\end{tabular}

Insect Infestation: During rainy season, humidity levels are high, sufficient drying cannot be achieved using traditional methods, processed and stored dried fishes re-absorb moisture and become susceptible to insect attack. Losses also result during storage from attack by pests which can gain access. The amount of quantitative loss by insect infestation was nearly $10 \%$. This amount increases during the rainy season $(15-20 \%)$ at Singra drying yards. It was noticed that two major infestations damage the dry fish products such as larvae (maggots) of several species of fly (Diptera) during the early stages and Beetle (both larvae and adult). Mite also infests during storage and in distribution. Mainly adult females lay their eggs on fish flesh. After hatching young larvae then feed fish muscle vigorously. Most of the damage in dry fishes is caused by the larval stage. More or less same results were reported by FAO (1981) and Nowsad (2007). They opined that insect infestations are the real problems in dry fish in Bangladesh. Bala (2000) reported that, in tropical climates under highly humid conditions, heavy infestation of unsalted dry fish by beetles may cause up to $30 \%$ loss of the products. Doe (1977) and Ahmed (1978) reported that both quantitative and qualitative losses occurred through spoilage and insect attack in dry fish processing.

Protection Policy: In the fish drying point (Singra, Chalan beel) there was no fly proof netting system (Plate 1). For this reason infestation by flies and beetles was very much common problem (Plate 2. A and B). To protect the dry fishes from the insects, dry fish professionals used different insecticides in different doses. Name of the insecticides and its doses are presented in Table 2 . 


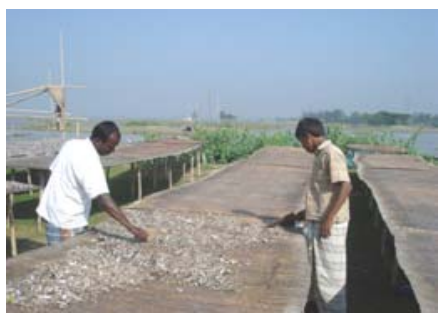

Plate 1. Showing open drying activity in the study area.
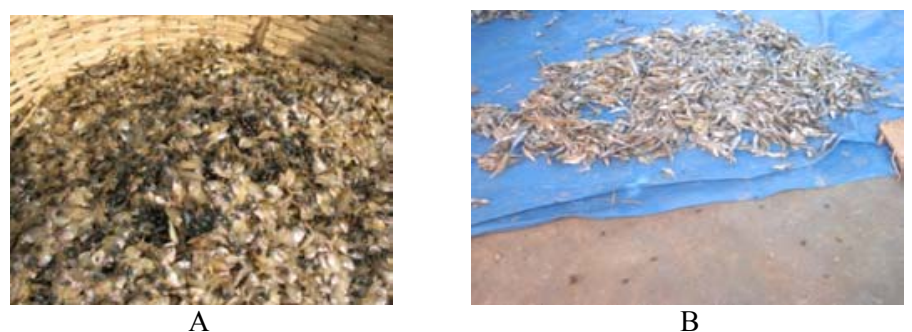

Plate 2. Showing the infestation of dry fish by cheese flies (A) and houseflies (B).

Table 2. Name and doses of the insecticides.

\begin{tabular}{|c|c|c|c|c|c|c|}
\hline \multirow[b]{2}{*}{$\begin{array}{l}\text { Sl. } \\
\text { No }\end{array}$} & \multirow[b]{2}{*}{$\begin{array}{c}\text { Name of } \\
\text { the } \\
\text { insecticides }\end{array}$} & \multirow[b]{2}{*}{$\begin{array}{l}\text { Name of the } \\
\text { company }\end{array}$} & \multirow[b]{2}{*}{ Price Tk. } & \multicolumn{3}{|c|}{ Doses } \\
\hline & & & & $\begin{array}{l}\text { Amount } \\
\text { of } \\
\text { medicine }\end{array}$ & $\begin{array}{l}\text { Amount } \\
\text { of water } \\
\text { mixed } \\
\text { with } \\
\text { medicine }\end{array}$ & $\begin{array}{l}\text { Amount } \\
\text { of fish } \\
\text { spread by } \\
\text { medicine }\end{array}$ \\
\hline 01 . & Basudin & $\begin{array}{c}\text { Sinzenta, } \\
\text { Bangladesh }\end{array}$ & $315(2 \mathrm{~kg})$ & $0.5 \mathrm{~kg}$ & --- & $200 \mathrm{~kg}$ \\
\hline 02. & Finish & $\begin{array}{l}\text { Standard finish oil } \\
\text { company, Dhaka }\end{array}$ & $27(100 \mathrm{~g})$ & $\begin{array}{l}\text { No actual } \\
\text { amount }\end{array}$ & $\begin{array}{c}\text { No } \\
\text { actual } \\
\text { amount }\end{array}$ & $\begin{array}{l}\text { No actual } \\
\text { amount }\end{array}$ \\
\hline & Booster & $\begin{array}{l}\text { Padma oli company, } \\
\text { Chittagong }\end{array}$ & $\begin{array}{c}432 \\
(400 \mathrm{ml})\end{array}$ & $400 \mathrm{ml}$ & 5 liter & $500 \mathrm{~kg}$ \\
\hline 04. & 总 & $\begin{array}{l}\text { National agricare } \\
\text { import and export } \\
\text { limited }\end{array}$ & $\begin{array}{c}465 \\
(400 \mathrm{ml})\end{array}$ & $400 \mathrm{ml}$ & 5 liter & $500 \mathrm{~kg}$ \\
\hline 05. & Diazinon & $\begin{array}{l}\text { The limit company, } \\
\text { Chittagong }\end{array}$ & $\begin{array}{c}300 \\
(400 \mathrm{ml})\end{array}$ & $400 \mathrm{ml}$ & 5 liter & $500 \mathrm{~kg}$ \\
\hline 06. & Camcrone & --- & $\begin{array}{c}60 \\
(50 \mathrm{ml})\end{array}$ & $50 \mathrm{ml}$ & 2 liter & $200 \mathrm{~kg}$ \\
\hline
\end{tabular}


Often the extent of pesticide use was sharply reduced in sunny days. If the storage time prolongs, processors check the condition of the stored products at certain intervals. If further infestation was found, the product was treated with the pesticides again after a day of drying. There was no indigenous method of protection of dried fishes from insects but salting. Most dry fish professionals use salts to protect their products from insects. Some fish traders use additional salt to increase the weight of dry fish but the quality of salts is very poor and not proper ratio of salt and fish is maintained.

In the study area the dry fish processors or labourers have no knowledge on pesticide action, dose limit and residual effects. Nowsad (2007) worked on tolerance limit of pesticides in dried fishes. For example $100 \mathrm{~g}$ Basudin (active ingredient: $100 \mathrm{~g}$ Diazinon in $1 \mathrm{~kg}$ ) is applied to $100 \mathrm{~kg}$ dried fish in gunny sacks during storage. He also reported, during processing Nogos, Nuvacron, Endrin, Malathion, Dimacron etc. are popularly used, while in storage of the product, DDT, Basudin and Malathion were preferred ones. Both insects and insecticides comprise about $60 \%$ of the total dried product that is considered to be unfit for human consumption (Nowsad 2005). Fish processors in Thailand were found to rely on the application of illegal insecticides to control blowfly infestation (Esser 1992). Clucas and Ward (1996) recommended insecticides applications by properly instructed trained people. Samad et al (2009) reported that generally mixed 25-50 kg commercial salt for $1 \mathrm{~kg}$ of fishes. Mushi and Chiang (1974) suggested that dried fish containing $13 \%$ or more salt could prevent the growth of insect at all developmental stages. Doe (1977) and Ahmed (1978) also reported that damage can be heavy where salt is not used and drying condition is poor, as much as $25-30 \%$ under very humid conditions in Bangladesh.

To keep the dried product free from the insect infestation proper training should be necessary for improvement of traditional sun-drying, good handling, sanitation and public health. Use of insecticides in dried fishes must be stopped and tent or funnel sun drier developed by AERC and BCIRL must be ensured.

\section{Acknowledgement}

The authors are grateful to the dry fish professionals of Singra, Chalan Beel, Bangladesh and other people associated with the study for their cordial cooperation.

\section{References}

Ahmed, M. 1978. Radiation disinfestations studies on sun-dried fish. Proc. IPFC. 18(3): 310-321. Azam, K. 2002. Fishermen Community of Kuakata, Bangladesh: Fisheries Activities and Quality of Dried Fish. Final Report, Support for University Fisheries Education and Research, DFID.194 pp.

Bala, B.K. 2000. Adaptive research on solar dryer for drying mango, pineapple and fish. Annual Research Report, Department of Farm Power and Machinery, Bangladesh Agricultural University, Mymensingh. 24pp. 
Basu, K.P. and K. Gupta. 2004. Biological value of protein of some species of Bengal fish by balance and growth methods. J. Indian. Chem. Soc. Calcutta. pp.543-548.

Clucas, I.J. and A.R. Ward. 1996. Post-harvest Fisheries Development: A Guide to Handling, Preservation, Processing and Quality. Chatham Maritime, KentME44TB, United Kingdom. 242 pp.

Doe, P.E. 1977. A polythene tent drier for improved sun-drying of fish. Food Technol. Aust. 29(11):437-441.

DoF, 2011. National Fish Week 2011. Department of Fisheries, Ministry of Fisheries and Livestock, Dhaka, Bangladesh. 136 pp.

DoF, 2012. National Fish Week 2012. Department of Fisheries, Ministry of Fisheries and Livestock, Dhaka, Bangladesh. 13 pp.

Esser, J.R. 1992. Reduction of insect infestation and losses of traditionally processed salted dried fish in Thailand. In: Investigations into treatment of salted-dried fish with insecticides. Report 1 Overseas Development Administration, London. 81:33-47.

FAO. 1981. The prevention of losses in cured fish. FAO Fisheries Technical No. 219. Food and Agriculture Organization of the United Nations, Rome.87pp.

Graikoski, J.T. 1998. Microbiology of cured and fermented fish. In: Microbial safety of fishery products. pp. 97-110.

Hossain, M.A. and S. Afroze. 1991. Small Fisheries as Resource in Rural Bangladesh. Fishbyte. 9(2):15-18.

Mushi, A. M. and H.C. Chiang. 1974. Laboratory observations on the effect of common salt on Dermestes maculatus Degeer (Colcoptera, Dermestidae) infesting dried, freshwater fish. Roccus Chrysop. StoredProd. Res. 10(1): 57-60.

Nettleton, J.A. 1992. Seafood nutrition in the 1990's: Issues for the consumer. In: Seafood Science and Technology (ed. Bligh. F, G). Fishing News Books, London. pp.32-39.

Nowsad, A.K.M.A. 2005. Low-cost Processing of Fish in Coastal Bangladesh. BGD/97/017 Field Doc: 05/2005. Food and Agriculture Organization of the United Nations. Dhaka. 73pp.

Nowsad, A.K.M.A. 2007. Participatory Training of Trainers: A New approach Applied in Fish Processing. Bangladesh Fisheries Research Forum. 328pp.

Ross, N., M.A. Wahab, C. Chamnan, and S.H. Thilsted, 2007. The role of fish in food-based strategies to combat vitamin A and mineral deficiencies in vitamin $\mathrm{A}$ and mineral deficiencies in developing countries. J. Nutr. 157: 1106-1109.

Samad, M.A., S.M. Galib. and F.A. Flowra. 2009. Fish drying in Chalan Beel areas. Bangladesh J. Sci. Ind. Res. 44(4): 461-466.

(Received revised manuscript on 11 September 2013) 